\title{
The Year of the Unthinkable
}

\begin{abstract}
COVID-19 brought the 'unthinkable' to our doorstep. The pandemic caused a series of global, and interconnected, health, economic, social, institutional and political crises that are unprecedented in living memory. Political leaders struggled to contain the virus and persuade anxious, weary citizens to behave this or that way in order to overcome a giant collective action problem. This chapter is a primer for the detailed examination of political and policy responses to this impossible challenge. It describes pivotal governance challenges and the constraints operating on the crisis response.
\end{abstract}

Keywords Transboundary crises - Pandemic - COVID-19 - Crisis politics · Crisis management

Nobody wanted 2020 to be this way-Canadian Prime Minister Justin Trudeau. (Lum, 2020)

Pandemics and plagues have a way of shifting the course of history, and not always in a manner immediately evident to the survivors. The COVID pandemic will be remembered as such a moment in history, a seminal event whose significance will unfold only in the wake of the crisis.-Anthropologist Wave Davis (2020) 


\section{ANNus HorribiLIS}

The year 2020 will be remembered for the global pandemic-a 'seminal event' (Davis, 2020)—that dwarfed all other global crises in living memory. By the year's end, COVID-19 had directly caused the deaths of nearly two million people, jeopardizing the health, well-being and livelihoods of hundreds of millions more. ${ }^{1}$ It was also an unwanted event, as Trudeau said (see opening quote). Pandemic control measures have pushed economies around the world abruptly into recession while emptying government coffers at astonishing rates. Global debt incurred as a result of COVID-19 has been estimated at $\$ 10$ trillion in 2020, rising up to $\$ 30$ trillion by 2023 (Assi et al., 2020).

Statistics alone cannot capture the human toll of the crisis. Families were separated from loved ones who died alone. One survivor, who had been hospitalized in the UK for several weeks, said that "I must have seen at least eight people die...... And the fear in people's eyes is shocking. .... It's like a nightmare with your eyes open" (Murray, 2020). A physician in New York described how his hospital was “... just getting destroyed. It's very, very gruesome.... I have one face shield that I have to keep rewashing after seeing every patient...It's pretty common to see [staff] crying in the hallway... The morale among ER people is extremely low. People are anxious, making morbid jokes about dying" (Bernstein, 2020).

People suffered in many other ways. They feared that they would lose their job or the business they had just started. Young people wondered whether they would ever get a job. Many patients experienced setbacks in their treatment plans as the hospitals were filled and non-urgent care was limited or cancelled. Kids got behind in school. People were lonely, as they could not see their loved ones or go out and make new friends.

The impact of COVID-19 was not equally distributed. The 'Great Pestilence' of our times exposed fragilities in healthcare systems, economic systems, and the fabric of social and institutional trust (Keane, 2020). The toll of the coronavirus deepened social fault lines of race, class, age and place. And, as happens in almost every crisis, COVID-19 also produced 'winners'-people and businesses that were granted unsuspected opportunities and made the most of it.

${ }^{1}$ The coronavirus disease 2010 (COVID-19) is caused by coronavirus SARS-COV-2. The numbers were found at https://covid19.who.int/. 
COVID-19 will enter the history books as a "mega-crisis" (Helsloot et al., 2012). The virus generated fear and suffering. The pandemic put extraordinary pressures on health systems. The crisis required tough decisions about the allocation of scarce resources and painful response measures.

Many political leaders will likely remember COVID-19 as the biggest crisis they had to manage. New York governor Andrew Cuomo spoke of ' 111 days in hell' during which he could barely sleep as his state and in particular New York City reeled from the impact of the pandemic (Sanchez, 2020). The Italian Prime Minister, Giuseppe Conte, put it this way: "I feel the pain of the gaping wound that this nation is experiencing.... Behind the numbers are names and surnames, life stories and broken families. The Italian nation is suffering" (Lowen, 2020). Canadian Prime Minister Justin Trudeau conveyed his exasperation: "COVID-19 really sucks... This is really difficult.... It is frustrating to have to go through this situation. Nobody wanted 2020 to be this way" (Lum, 2020).

We also witnessed amazing successes. Entire nations pulling together as one, with 'teams of millions' displaying remarkable self-discipline and adaptive capacity (Jetten et al., 2020). Governments following science, taking the politics out of the response. Governments in East Asia implementing the lessons from earlier experiences (2003's SARS, 2009's swine flu and 2015's MERS) (Moon, 2020). Countries such as Vietnam and New Zealand pursuing early and aggressive elimination strategies that left them nearly virus-free throughout 2020 .

Some leaders reaped the political benefits of perceived effectiveness. Germany's veteran chancellor Angela Merkel, who was on her way out of politics before the pandemic began, saw a stunning reversal of her approval ratings (Armstrong, 2020). New Zealand Prime Minister Jacinda Ardern came within a hair's breadth of winning an absolute majority in the October 2020 parliamentary election, a remarkable feat under the country's proportional representation voting system.

But the governance of COVID-19 response has also been marred by conspicuous failures and intense politicization. There was the UK's initial and ill-conceived pursuit of a 'herd immunity' strategy and the cavalier attitude of its Prime Minister, Boris Johnson. There were nasty disinformation campaigns. There was the deep disenchantment among the population of France with its government's heavy-handed response. There was the unedifying infighting between state administrations and Donald 
Trump's White House. There were heads of government describing the virus as a hoax, bathing in crowds, hugging and shaking hands. There was the deep concern about governments using the crisis to acquire and wield far-reaching executive powers, the undermining of checks and balances and violating human rights-trampling principles of good governance.

How does one govern during a lethal pandemic? Governments everywhere faced challenges that we know from dystopian disaster movies (Bostrom \& Ćirković, 2008). In an idealized world, we might expect existential threats to be met with a mixture of effectiveness, empathy, legitimacy and de-politicization. We would expect political elites, business leaders and citizens working hand in hand, doing what they can to conquer the virus and allay collective fears. That did not always happen.

Helping us grasp the governance of COVID-19, warts and all, is the key objective of this book. We seek to capture the mix of challenges and opportunities that COVID-19 brought to public policymakers and political actors. We contemplate how leaders, governments and public institutions navigated this extraordinarily deep and protracted crisis. Simple questions guide our quest. How have our systems of public governance performed in the greatest stress test of our times? What lessons do we really need to learn if our systems are to be resilient enough to cope with and bounce back from the next mega-crisis?

\section{A Crisis Perspective on Pandemic Governance}

The Black Plague of the Middle Ages killed an estimated $40-60 \%$ of the people in Europe, Africa and the Middle East (Green, 2015). Every century since has produced pandemics of varying scale and severity, including typhus, cholera, small pox and influenza. In a period of roughly 2 years from early 1918 to late 1919 at the tail end of World War I, a global pandemic, commonly known as 'Spanish Flu' infected roughly half a billion people (one-third of the world's population) and killed at least 30 million people (Barry, 2004; Phillips \& Killingray, 2003). Many deadly pandemics have followed since (AIDS, MERS, SARS, HINl, Ebola).

A community of public health experts, including virologists and epidemiologists, studies how communities and their leaders should prepare for such threats. They try to establish which measures should be taken in which phase of an emerging pandemic. Specialized organizations such as the World Health Organization (WHO), the US Centers 
for Disease Control (CDC) and the European Centre for Disease Prevention and Control (ECDC) take stock of research findings and translate these findings into protocols. Each new pandemic thus poses a test to the current knowledge of this international community.

Each pandemic also tests the more generic capacity of a community to deal with an unexpected and major threat to the well-being of that community and its members. In recent years, the world has seen many 'mega-crises' and disasters. Governments everywhere have ramped up preparation and response structures as they face the prospect of future crises that dwarf the scope of previous threats.

Researchers from different disciplines seek to understand how governments, businesses, NGOs and international organizations respond to such large-scale contingencies. The umbrella term of 'crisis' has become increasingly popular in capturing the special challenges that this class of events entails (McConnell, 2020). In this book, we conceptualize crises not in terms of their physical properties such as deaths and damage, but in terms of how political-administrative elites perceive the events in question. We speak of a crisis when the governing elites perceive "a serious threat to the basic or the fundamental values and norms of a social system, which - under time pressure and highly uncertain circumstances - necessitates making critical decisions" (Rosenthal et al., 1989, p. 9).

A combination of threat, uncertainty and urgency unsettles the routines of political decision-making, policy implementation and public service delivery. The perception of threat raises the stakes of governing. It generates intense media attention and arouses strong public emotionsan explosive mix for incumbent politicians. When the threat is deemed not just serious but urgent, politicians and policymakers are robbed of an important problem-solving mechanism: time. They have no time to analyse, deliberate, negotiate and procrastinate. High levels of uncertainty about the precise nature, impact and duration of the perceived threat make it hard to organize an effective response. Leaders discover to their dismay that they have to make highly consequential decisions based on nothing but gut feelings or political judgement.

To manage a crisis under these circumstances, two types of expertise or 'craft' are needed. As a professional craft, crisis management is about scenario modelling, contingency planning, mobilizing response capacity, making tough decisions, coordinating the efforts of different agencies and jurisdictions, moving from response to recovery and ensuring that the crisis experience is thoroughly investigated and lessons are learned. 
As a political craft, it is about the strategic framing of the nature and causes of threats, the social distribution of risk and harm across groups and interests, exploiting opportunities to capture the limelight and shift policy agendas, claiming credit or navigating blame games and pushing for, or blocking, systemic reforms.

Wielding a crisis perspective helps us to see that many of the problems that emerged during the COVID-19 crisis were very similar to the challenges that typically occur in all sorts of crises. For example, COVID19 watchers have often been confounded by the depth of uncertainty, the dynamics of public perceptions and the ways in which politicians and other actors 'talk up' or 'talk down' the scope, origins and severity of the pandemic. All this is standard fare for crisis analysts (Boin et al., 2009; Boin \& Lodge, 2016; Brändström \& Kuipers, 2003; De Vries, 2004; Drennan et al., 2015).

A crisis perspective also helps us to see the unique characteristics of COVID-19, which have made the response to this threat such an ordeal. Let us take a look at these characteristics and contemplate how they made the response more difficult than public health experts appear to have imagined beforehand.

\section{The Unique Characteristics of the COVID-ig Crisis}

What places the coronavirus pandemic in a class of its own is the combination of three types of characteristics. COVID-19 qualifies as a creeping crisis, as the pandemic stretched out over time (Boin et al., 2020). COVID-19 was a transboundary crisis, crossing geographical, jurisdictional and sectoral borders (Boin \& Rhinard, 2008). It was also a solidarity crisis - a massive collection action challenge, as the great majority of people was not directly threatened by the disease but was asked or compelled to make sacrifices in order to suppress the virus. This is a rare combination, which creates special types of challenges. Let us discuss the characteristics and the governance challenges that flow from them in more detail.

\section{Incubation and Rapid Escalation}

There was no a clear beginning (no 'big bang'), just an increasing stream of worrying signals. The world watched closely how the Chinese mounted an all-out response. Many experts dismissed the new coronavirus as yet 
another virus mutation that would probably be nipped in the bud or would turn out to be not all that dangerous (like $\mathrm{HlNl}$ ).

But the coronavirus escaped China and spread across the world. On 1 February 2020, there were just over 12,000 cases globally and 259 deaths. ${ }^{2}$ When the virus manifested itself in one country after another, many leaders were surprised by the scale of the crisis. The crisis eventually disappeared, at least for a while, and returned with a vengeance in many countries (the second and third waves). As we write this, it is still not clear when and how this crisis will end (see also Chapter 5).

\section{A Solidarity Crisis}

COVID-19 was more than 'just' a respiratory illness. The disease could inflict chronic damage on major organs (particularly the heart, kidneys and lungs) and impair neurological functions to the point of long-term debilitation and death (Roberts et al., 2020). The elderly, people with certain underlying health conditions (such as obesity, immune system deficiencies, diabetes), the socially disadvantaged and people living in high-density communities ran markedly higher risks of getting seriously ill or dying from the effects of the virus.

In theory, no one was immune, not even the rich, famous and powerful: Donald and Melania Trump and Ivana Trump, Boris Johnson, Prince Charles, Usain Bolt, Tom Hanks, Marianne Faithful, Placido Domingo, Silvio Berlusconi and Emmanuel Macron contracted the disease (to name but a few). Most people who got it, did not get sick. Over time, this well-publicized pattern began to gnaw at the credibility of the crisis response. Small but vocal groups of 'dissenting' medical practitioners, economists and citizens questioned government claims about the virus and its consequences. Conspiracy theories about the origins of the virus and the 'real' objectives of politicians or business elites-Bill Gates and George Soros figured prominently-flourished.

The rapidly deepening economic malaise set the stage for an intense political debate about the trade-off between the health of at-risk groups and the prosperity and well-being of society. Critics charged that governments were stupidly persevering with social distancing, lockdowns and other restrictions that were accomplishing very little (saving the lives of

${ }^{2}$ Data is from the Johns Hopkins Coronavirus Research Center. 
the very old and infirm, many of whom had limited life expectancies) at a phenomenal price (extensive damage to the prosperity, well-being and indeed the health of the other $98 \%$ of the population). Perceptions shifted again when hospitals filled to capacity and ambulances had to wait for hours to have their patients submitted to the hospital. In hindsight, the UK's original impulse towards a 'herd immunity' strategy is perceived by many as a callous sacrifice of vulnerable citizens (Hunter, 2020).

\section{Multiple Domains, Multiple Crises}

The pandemic was not confined to a delineated geographical location (a "Ground Zero") nor did it fall neatly within the jurisdiction of one governmental entity. There was no self-evident jurisdictional or sectoral point of gravity from which response efforts should be organized. Many actors at all levels of governance and in all corners of society, each with different sets of concerns, resources and responsibilities assumed a role in the crisis response. This created considerable discussion and sometimes tensions about who is 'in charge' and of what exactly. The pandemic severely tested the capacity of existing systems of intergovernmental relations-particularly in federal systems of government and in multilevel polities like the European Union-to mount coherent responses and prevent politically damaging blame games.

Moreover, the pandemic produced more than a health crisis. It gave rise to a complex and multifaceted intersection of numerous crises. We give a few examples:

An economic crisis. The economic challenges of COVID make the global financial crisis that began in 2008 look tame by comparison. The mitigation measures had dire economic consequences: massive job losses, reduced investment, downsizing and bankruptcies, declining tax revenues. Massive stimulus measures and rapidly escalating social spending created enormous budgetary shortfalls. Debt levels soared. Economically precarious sectors such as the arts, high-street retailers, hospitality, farming and public transportation faced unprecedented conditions in terms of reduced demand and/or reduced income. In the tourist sector alone, roughly 305 million jobs were at stake (International Labour Organisation, 2020).

A social crisis. The pandemic exacerbated pre-existing inequalities in most if not all societies (Blundell et al., 2020). For example, Black people in the US were 2.5 times more likely to die from the virus than white people 
(Kaur, 2020). In Spain, the impact of lockdown measures had a harsher effect on low-paid, lower-educated workers, with women being particularly affected because of large increases in childcare and housework (Farre et al., 2020). Around the world, large numbers of schoolchildren from underprivileged backgrounds suffered the consequences of protracted school closures. Containment measures had a negative effect on domestic violence, child poverty and alcohol abuse. Mental health experts issued dire warnings about the long-term impacts of the crisis on people with pre-existing mental health conditions.

A political crisis. In any crisis, core values in a system are at stake. They may become endangered and violated. They are defended, fought over, reconfirmed or traded-off against one other. In the process, previously taken-for-granted political commitments and the coalitions supporting them may be shattered. The cross-cutting impacts of the pandemic forced critical choices on virtually every country, every organization, every community, every family and each person. COVID-19 threatened to splinter societies, increase ethnic conflicts, and fuel radicalization and undermine trust in science and expertise (Woods et al., 2020). The COVID-19 crisis was deeply political and unleashed a series of challenges for politicians, policymakers and public institutions.

Many doubted whether governments were up to the task of managing this multi-crisis. A recurrent criticism was directed at the apparent refusal of political leaders to listen to scientific experts. There was the related charge that governments were listening to a far too narrow set of experts-i.e. epidemiologists, but not economists or social scientists. Another complaint held that leaders were captured by an experts-driven technocratic mode of policymaking and downplayed legitimate considerations beyond the realm of scientific expertise. The structures and processes of government were criticized as too slow, too opaque, complacent and starved of resources (Gaskell et al., 2020; Pargoo, 2020; Ruiu, 2020).

The performance of public institutions became subject of critical discussion. Were the incentives and resources of healthcare systems properly set up to absorb the onslaught of COVID patients? Did critical information reach the right organizations and the highest levels of government? Were organizations able to cast aside their standard operating procedures and effectively improvise? Were governments able to overcome the usual institutional pathologies-organizational silos, 
bureaucratic politics, intergovernmental stalemates and blame shiftingthat make it so difficult to tackle complex problems? Were the institutional guardians of democracy and the rule of law robust enough to provide the required checks and balances on executive power?

Judgments about institutional performance varied widely. In countries like South Korea, Vietnam, Taiwan and New Zealand, the sense of unity of purpose and collective achievement in eradicating the virus was strong. The COVID experience triggered a celebration of institutions. In other countries, there was overt institutional strife, sometimes producing policy stalemate and political standoffs. Critics of the status quo had plenty of arguments to advocate for reform.

There was also a human rights (or libertarian) dimension: governments were accused of exploiting the crisis to pass draconic emergency laws giving them even more powers than they already possessed.

\section{Resulting Challenges}

One consequence of these unique characteristics was that the crisis remained hard to grasp. The root causes of a crisis that originated in another country or sector are difficult to comprehend. Causes are unclear, possible consequences seem uncertain, and escalation is unpredictable. Not just in the initial stages of the pandemic, but months into it, COVID19 kept throwing up questions that could not be answered. In that sense, it remained what it was from the outset: a rude surprise, in which not-knowing was chronic rather than ephemeral.

Epidemiological research worldwide has been operating at a frenetic pace since February 2020, but by the year's end much remained unknown about the exact behaviour of the coronavirus. Research and data gathering faced many complications, including the absence of testing (in cases of those who asymptomatic or have only mild symptoms), the variability of testing regimes, contextual variations in community beliefs and behaviours, and differences in policy settings and response capacity of health systems. ${ }^{3}$ Exacerbating the uncertainty was the time lag that can

${ }^{3}$ One key uncertainty is the infectiousness of the virus. The basic reproduction number (Ro) is an indicator of transmission. Whereas the Ro for influenza is stable and predictable, coronavirus reproduction numbers were hard to measure and appeared to vary markedly in both time and place (Linka et al., 2020). 
occur between the point of infection and the onset symptoms, which can vary from a few days to two weeks.

A second consequence was the difficulty of formulating working strategies. For most policy issues, possible solutions exist. They may be controversial or taken for granted. A pandemic defies easy solutions. What works here may not work there. COVID-19 caused multiple problems: not one but many strains of the virus; different health impacts across different demographics; seasonal and other geo-spatial factors mitigating its transmission; low SES groups and regions much harder hit than affluent ones; a complex mix of direct (health) and indirect (secondary health, psychosocial, socio-economic, supply-chain, political, even geopolitical) impacts.

Policymakers faced numerous urgent issues they had to decide on: testing, protective masks, medical equipment, contact tracing, stay-athome orders, restrictions on gatherings from funerals to sporting events, mask wearing, curfews, shutting down of parts of the economy, the care system, the education system, income support and business continuity packages. No ready-made solutions existed. Navigating these challenges required improvisation. Responses were always provisional, had significant unintended consequences and were open to contestation.

\section{How Did It Go? First Impressions}

We expect our governments to 'rise to the occasion' when a crisis rears its head. We expect crisis leaders and crisis systems to rapidly shift into crisis mode, drawing on contingency plans and extensive preparation. We expect the 'public interest' to prevail: political leaders and the systems they preside over should put aside party politics, career ambitions and bureaucratic politics. They should be decisive, explain their strategy and demonstrate empathy and compassion.

Ever since World War II, a broad array of crises and disasters has punctuated the progress of affluent and stable Western societies. The COVID-19 crisis has put the resilience of these societies and their governments to their sternest test yet. Although it is far too early to pass definitive judgement on government performance in the face of COVID-19, a few stage-setting observations can be made at this point in time. 


\section{Our Systems Were Not Designed for Pandemics}

Political systems, public institutions and policy processes were clearly not built to deal with a serious pandemic. In fact, these systems are not built to deal with mega-crises. The systems were developed incrementally over time to deliver public sector services such as health, education and welfare in an effective, efficient and legitimate way. That proves hard enough on a daily basis. Contingency plans, risk management planning and crisis response systems were 'add-ons'. Designing capacities to deal with plausible worst-case scenarios has never been core business of most governing systems.

\section{Systems Were Stretched to Breaking Point}

The COVID-19 crisis frequently outstripped public sector capacities. In many countries, hospitals and healthcare systems were close to collapse. Governments struggled with testing and tracing, enforcing lockdowns and devising emergency relief measures. Quite a few governmental systems were unable to produce a coherent strategy or a coordinated approach to solving critical problems.

\section{Controversy About Response Strategies}

Many countries devised policies that proved wanting. The timing and the scope of lockdown measures proved controversial: draconian measures but also easing restrictions followed by second waves. 'Following the science' was the mantra for many governments, which led some societies down surprising and controversial paths. Governments had to contend with protests and resistance from virus deniers, anti-maskers, conspiracy theorists and libertarians opposed to 'Big Brother' lockdowns and imposed restrictions.

\section{Success Stories}

It was not all doom and gloom. Some governments introduced effective measures (e.g. New Zealand and China). Some otherwise disjointed and chronically contentious federal polities managed to produce remarkably well-coordinated responses (Germany, Canada, Australia). Some government leaders turned into highly astute interpreters of scientific 
issues (Merkel in Germany, Tsai Ing-Wen in Taiwan) whereas powerful displays of empathy characterized the crisis performances of others (such as Jacinda Ardern in New Zealand and Sanna Marin in Finland). Many public sectors proved quite adroit in adapting to the crisis landscape, which was all the more remarkable because of the millions of public officials working from home.

Government agencies devised and rolled out economic aid programmes at astonishing speed and to great positive effect. Leaders abandoned their electoral platforms and ideological proclivities to do what was deemed necessary. Governments managed to effectively harness enormous bursts of bottom-up community initiatives. Supply chains held (the shelves did not go empty). Businesses rapidly adapted their operating models. Levels of trust in government (and in 'science') soared in many countries and often remained high despite setbacks, controversies and, sometimes, open admissions of failures of pre-crisis preparedness and early-period responses.

\section{A Preview of the Book}

COVID-19 was a complex multi-system crisis that challenged the political foundations of modern states. We examine these challenges in detail in the rest of this book, employing a crisis management perspective. Each chapter focuses on a particular crisis task (Boin et al., 2016).

Chapter 2 analyses how leaders and public authorities made sense of the emerging global pandemic. We explore the classic tension between what in retrospect always appear to be obvious threats and the 'why didn't they seem it coming?' narrative that typically dominates when the first signs of the crisis appear. In this chapter, we study how leaders and experts made sense of the reported cases in Wuhan, how they assessed the building threat and how the relation between experts and crisis leaders shaped the initial response.

Chapter 3 examines governmental responses to the crisis. We describe the challenges of transboundary crisis management. We explain why political leaders must juggle multiple pressures, which emanate from different types of crisis (particularly health and economic), and how they seek to contain and control threats over which they have limited control.

Chapter 4 addresses crisis communication during the pandemic. In times of crisis, authorities have to weave and communicate believable narratives about what is going on, what is at stake, what government is 
doing in response, what people can do to keep themselves and others safe. We discuss how leaders do this in the context of 'framing contests'-they are, after all, not the only ones who try to get their message across.

Chapter 5 discusses the politics of closure. It is a salient issue in the COVID-19 crisis, which may drag on for years. The desire to declare that it is over after cases and deaths have subsided is understandable, certainly when the economy is struggling and citizens are suffering from the fatigue of COVID restrictions. But that desire needs to be balanced with the realistic possibility of new waves. This chapter outlines the many challenges that political leaders have to negotiate on their way to the exit.

Chapter 6 addresses the big question of 'what next?' We focus on the struggle between the impulses of preservation, consolidation and returning to 'normal', but also the impulses for reform, forging new policies and alliances that would not have been possible without the norm-shattering impact of the COVID-19 crisis. We provide ideas to move countries down the road that leads to societal resilience.

\section{BIBLIOGRAPHY}

Armstrong, M. (2020, October 8). 15 years of Angela Merkel. Statista. https:// www.statista.com/chart/23144/merkel-opinion-polls-since-2005/.

Assi, R., de Calan, M., Kaul, A., \& Vincent, A. (2020, July 16). Closing the $\$ 30$ trillion gap: Acting now to manage fiscal deficits during and beyond the COVID-19 crisis. McKinsey \& Company. https://www.mckinsey.com/indust ries/public-and-social-sector/our-insights/closing-the-30-trillion-gap-actingnow-to-manage-fiscal-deficits-during-and-beyond-the-covid-19-crisis.

Barry, J. M. (2004). The great influenza: The epic story of the deadliest plague in history. Penguin Books.

Bernstein, J. (2020, March 26). A chilling account from a doctor at the center of the coronavirus crisis. Buzzfeed News. https://www.buzzfeednews.com/art icle/josephbernstein/elmhurst-hospital-coronavirus-ventilator-ppe-crisis.

Blundell, R., Costa Dias, M., Joyce, R., \& Xu, X. (2020). COVID-19 and inequalities. Fiscal Studies, 41(2), 291-319.

Boin, A., \& Lodge, M. (2016). Designing resilient institutions for transboundary crisis management: A time for public administration. Public Administration, 94(2), 289-298.

Boin, A., \& Rhinard, M. (2008). Managing transboundary crises: What role for the European Union? International Studies Review, 10, 1-26.

Boin, A., Overdijk, W., Van der Ham, C., Hendriks, J., \& Sloof, D. (2020). COVID-19: Een analyse van de nationale crisisrespons. Crisis University Press. 
Boin, A., 't Hart, P., \& McConnell, A. (2009). Crisis exploitation: Political and policy impacts of framing contests. Journal of European Public Policy, 16(1), 81-106.

Boin, A., 't Hart, P., Stern, E., \& Sundelius, B. (2016). The politics of crisis management. Cambridge University Press.

Bostrom, N., \& Ćirković, M. M. (Eds.). (2008). Global catastrophic risks. Oxford University Press.

Brändström, A., \& Kuipers, S. (2003). From 'normal incidents' to political crises: Understanding the selective politicization of policy failures. Government and Opposition, 38(3), 279-305.

Davis, W. (2020, August 6). The unravelling of America. Rolling Stone. https://www.rollingstone.com/politics/political-commentary/covid19-end-of-american-era-wade-davis-1038206/.

De Vries, M. S. (2004). Framing crises: Response patterns to explosions in fireworks factories. Administration \& Society, 36(5), 594-614.

Drennan, L. T., McConnell, A., \& Stark, A. (2015). Risk and crisis management in the public sector (2nd ed.). Routledge.

Farre, L., Fawaz, Y., Gonzalez, L., \& Graves, J. (2020). How the COVID19 lockdown affected gender inequality and paid and unpaid work in Spain (IZA Discussion Paper, 13434). https://papers.ssrn.com/sol3/papers.cfm? abstract_id=3643198.

Gaskell, J., Stoker, G., Jennings, W., \& Devine, D. (2020). Covid-19 and the blunders of our governments: Long-run system failings aggravated by political choices. The Political Quarterly, 91(3), 523-533.

Green, M. H. (2015). Editor's introduction to pandemic disease in the medieval world: Rethinking the black death. In M. H. Green (Ed.), Pandemic disease in the medieval world: Rethinking the black death (pp. 9-26). ARC Humanities Press.

Helsloot, I., Boin, A., Comfort, L., \& Jacobs, B. D. (Eds.). (2012). Mega-crises: Understanding the prospects, nature, characteristics and effects of cataclysmic events. Charles C. Thomas.

Hunter, D. J. (2020). COVID-19 and the stiff upper lip: The pandemic response in the United Kingdom. New England Journal of Medicine, 382(31), 1-3.

International Labour Organisation. (2020). The impact of COVID-19 on the tourism sector. ILO.

Jetten, J., Reicher, S. D., Haslam, S. A., \& Cruwys, T. (2020). Together apart: The psychology of COVID-19. Sage.

Kaur, H. (2020, May 9). The coronavirus pandemic is hitting black and brown Americans especially hard on all fronts. CNN. https://edition.cnn.com/ 2020/05/08/us/coronavirus-pandemic-race-impact-trnd/index.html.

Keane, J. (2020, April 17). Democracy and the great pestilence. Eurozine. https://www.eurozine.com/democracy-and-the-great-pestilence/. 
Linka, K., Peirlinck, M., \& Kuhl, E. (2020). The reproduction number of COVID-19 and its correlation with public health interventions. Computational Mechanics, 66, 1035-1050. https://doi.org/10.1007/s00466-02001880-8.

Lowen, M. (2020, April 9). Coronavirus: EU could fail over outbreak, warns Italy's Giuseppe Conte. BBC. https://www.bbc.com/news/world-europe52224838 .

Lum, Z.-A. (2020, October 29). Trudeau says ongoing COVID-19 pandemic 'really sucks,' warns of 'tough winter' ahead. Huffington Post. https://www.huffingtonpost.ca/entry/justin-trudeau-covid-reallysucks_ca_5f9866ecc5b6740dfba27606.

McConnell, A. (2020). The politics of crisis terminology. Oxford Research Encyclopaedia of Politics. https://doi.org/10.1093/acrefore/9780190228637. 013.1590.

Moon, M. J. (2020). Fighting COVID-19 with agility, transparency and participation: Wicked problems and new governance challenges. Public Administration Review, 80(4), 651-656.

Murray, J. (2020, June 28). Case study: Covid-19 UK survivor recalls her all too real 'nightmare'. The Guardian. https://www.theguardian.com/soc iety/2020/jun/28/case-study-covid-19-uk-survivor-recalls-her-all-too-realnightmare.

Pargoo, M. (2020). Denials, delay and conspiracy theories: Iran's Covid mismanagement. The Interpreter. https://www.lowyinstitute.org/the-interp reter/denials-delays-and-conspiracy-theories-iran-s-covid-mismanagement.

Phillips, H., \& Killingray, D. (2003). Introduction. In H. Phillips \& D. Killingray (Eds.), The Spanish Influenza pandemic of 1918-19 (pp. 1-25). Routledge.

Roberts, C. M., Levi, M., McKee, M., Schilling, R., Lim, W. S., \& Grocott, M. P. W. (2020). COVID-19: A complex multi-system disorder. British Journal of Anaesthesia, 125(3), 238-242.

Rosenthal, U., 't Hart, P., \& Charles, M. T. (Eds.). (1989). Coping with crises. Charles C. Thomas.

Ruiu, M. L. (2020). Mismanagement of Covid-19: Lessons learned from Italy. Journal of Risk Research, 23(7-8), 1007-1020.

Sanchez, R. (2020, June 19). New York governor gives final coronavirus briefing after ' 111 days of hell'. CNN. https://edition.cnn.com/2020/06/19/us/ andrew-cuomo-final-coronavirus-briefing/index.html.

Woods, E. T., Schertzer, R., Greenfield, L., Hughes, C., \& Miller-Irdiss, C. (2020). COVID-19, nationalism, and the politics of crisis-A scholarly exchange. Nations and Nationalism, 1-19. https://doi.org/10.1111/nana. 12644. 
Open Access This chapter is licensed under the terms of the Creative Commons Attribution 4.0 International License (http://creativecommons.org/licenses/ by $/ 4.0 /$ ), which permits use, sharing, adaptation, distribution and reproduction in any medium or format, as long as you give appropriate credit to the original author(s) and the source, provide a link to the Creative Commons license and indicate if changes were made.

The images or other third party material in this chapter are included in the chapter's Creative Commons license, unless indicated otherwise in a credit line to the material. If material is not included in the chapter's Creative Commons license and your intended use is not permitted by statutory regulation or exceeds the permitted use, you will need to obtain permission directly from the copyright holder.

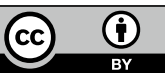

